\title{
Evapotranspiration and crop coefficient of drip-irrigated winter wheat in China's Xinjiang Province
}

\author{
Jie $\mathrm{Li}^{\mathrm{a}}$, Jing Cui ${ }^{\mathrm{a}}$, Rui Chen ${ }^{\mathrm{a}}$, Ping Yang ${ }^{\mathrm{a}}$, Yang-huan $\mathrm{Wu}^{\mathrm{b}}$, Shun-xi Chai ${ }^{\mathrm{a}}$, Fuyu Ma ${ }^{\mathrm{a}, *}$ \\ a Agricultural College, \\ Shihezi University/Key Laboratory of Oasis Ecology Agricultural of Xinjiang Bingtuan, Shihezi, \\ Xinjiang 832000, China \\ b Sixth Division Agricultural Science of Xinjiang Production and Construction Corps, Wujiaqu, \\ Xinjiang 831300, China
}

*Corresponding author, e-mail: mafuyu_123@sina.com

Received 26 Oct 2015

Accepted 14 Mar 2016

\begin{abstract}
Drip-irrigated winter wheat (Triticum aestivum) is grown on $5.07 \times 10^{5}$ ha in China's Xinjiang Uyghur Autonomous Region. Information about evapotranspiration (ET), evaporation, and crop coefficient $\left(K_{\mathrm{c}}\right)$ is important for maximizing water savings in drip-irrigated wheat. A field experiment was conducted during two winter wheat growing seasons at the Shihezi University Agricultural Experiment Station, Xinjiang Province. The study included three irrigation amounts $(375,600$, and $750 \mathrm{~mm}$, abbreviated D1, D2, and D3, respectively). The results showed that the ET of drip-irrigated winter wheat generally increased as irrigation increased. Averaged across both growing seasons, average daily ET rates decreased significantly in the order D3 $(2.64 \mathrm{~mm} / \mathrm{d})>\mathrm{D} 2(2.26 \mathrm{~mm} / \mathrm{d})>\mathrm{D} 1(1.55 \mathrm{~mm} / \mathrm{d})$. Evaporation was greatest between 1 and 4 days after irrigation and accounted for 26-28\% of ET during the entire growing season. The $K_{\mathrm{c}}$ values ranged between 0.45 and 1.35 across all growth stages, averaging 0.96. A fourthorder polynomial equation $\left(R^{2}>0.75\right)$ describes the changes in $K_{\mathrm{c}}$ across the growing season. A logarithmic function $\left(R^{2}>0.96\right)$ described the relationship between $K_{\mathrm{c}}$ and the leaf area index. The average yield was greater in D3 $(10520 \mathrm{~kg} / \mathrm{ha})$ than in D2 $(10060 \mathrm{~kg} / \mathrm{ha})$ and D1 (8000 kg/ha) in both years. The water use efficiency in D1 was 1.14-1.16 times that in D2, and 1.27-1.30 times that in D3. Thus considering the yield, the water use efficiency, and the harvest index, the optimum irrigation amount was $600 \mathrm{~mm}$. These results are helpful for improving irrigation management and crop water use predictions in Xinjiang Province and elsewhere in the world with similar irrigation methods and climatic conditions.
\end{abstract}

KEYWORDS: yield, soil evaporation, leaf area index, soil water, water use efficiency

\section{INTRODUCTION}

Drip irrigation has been used around the world to increase crop production and water use efficiency (WUE). Drip irrigation consists of frequent application of small amounts of water to the soil. This reduces water loss due to percolation below the crop root zone. Drip irrigation also influences water loss by evapotranspiration (ET) through its effects on the root zone soil water status and the field microclimate $^{1}$.

ET is the main component of the soil-plantatmosphere continuum, accounting for more than $90 \%$ of total agricultural water use $\mathrm{e}^{2,3}$. Because of its effects on both the water balance and the heat balance, ET is a key link in the hydrological cycle ${ }^{4}$.
There is a close relationship between ET and crop physiological activity. Furthermore, ET influences on crop growth and yield ${ }^{5,6}$.

Accurate determination of ET is critical for improving WUE and for developing suitable irrigation schedules 7,8 . Weighing lysimeters, which are the standard method for measuring crop ET, can capture information about ET over time periods as short as $30 \mathrm{~min}$. Large weighing lysimeters have been used to study ET in flood-irrigated winter wheat (Triticum aestivum) fields on the North China Plain $^{9,10}$. The authors reported that the evaporation (E) to evapotranspiration ratio (E/ET) was $30 \%$ in northern China. Gao reported that the ET for subsurface drip-irrigated winter wheat with three irrigation treatments ranged from $393-449 \mathrm{~mm}$ on 
Table 1 Monthly means for daily air temperature, daily solar radiation, relative humidity, rainfall, and evaporation during the winter wheat growing period in Shihezi.

\begin{tabular}{|c|c|c|c|c|c|c|c|c|c|c|}
\hline & \multicolumn{2}{|c|}{ Mean temp. $\left({ }^{\circ} \mathrm{C}\right)$} & \multicolumn{2}{|c|}{ Solar rad. $\left(\mathrm{MJ} \mathrm{m}^{-2} \mathrm{~d}^{-1}\right)$} & \multicolumn{2}{|c|}{ Relative humidity (\%) } & \multicolumn{2}{|c|}{ Rainfall (mm) } & \multicolumn{2}{|c|}{ Evaporation (mm) } \\
\hline & Y13-14 & Y14-15 & Y13-14 & Y14-15 & Y13-14 & Y14-15 & Y13-14 & Y14-15 & Y13-14 & Y14-15 \\
\hline Oct & 11.3 & 9.8 & 11.1 & 12.3 & 56 & 69 & 9.5 & 8.3 & 50.2 & 45.6 \\
\hline Nov & 0.3 & 0.1 & 8.7 & 9.5 & 76 & 77 & 11.7 & 10.2 & 15.5 & 12.6 \\
\hline Dec & -6.3 & -13.5 & 6.3 & 6.9 & 82 & 86 & 12.4 & 8.8 & 8.3 & 6.1 \\
\hline Jan & -14.2 & -15.5 & 5.4 & 5.8 & 78 & 89 & 8.9 & 5.2 & 5.9 & 3.4 \\
\hline Feb & -15.6 & -14.7 & 4.6 & 5.3 & 73 & 85 & 8.3 & 10.5 & 18.6 & 14.6 \\
\hline Mar & -0.6 & 2.7 & 12.3 & 11.5 & 69 & 71 & 7.6 & 8.4 & 65.2 & 60.3 \\
\hline Apr & 12.5 & 14.0 & 17.8 & 18.9 & 47 & 49 & 5.5 & 7.5 & 160.6 & 162.5 \\
\hline May & 20.8 & 22.1 & 22.4 & 23.7 & 33 & 29 & 5.2 & 6.2 & 208.5 & 194.2 \\
\hline Jun & 24.8 & 26.7 & 24.6 & 24.9 & 41 & 38 & 7.9 & 7.2 & 223.2 & 220.8 \\
\hline
\end{tabular}

Abbreviations: Y13-14, year 2013-2014; Y14-15, year 2014-2015.

the North China Plain ${ }^{11}$. Water use efficiency and yield are both greater under drip irrigation than under either furrow irrigation or sprinkler irrigation $^{12}$. Irrigation efficiency (or water application efficiency) under drip irrigation systems ranges between $75-95 \%$ compared with $25-50 \%$ for surface irrigation (furrow or block), $70-80 \%$ for fixed set sprinklers, and $65-75 \%$ for portable sprinkler systems ${ }^{13}$. To our knowledge, $E$ and ET in dripirrigated winter wheat fields in China's Xinjiang Province have not been studied.

The crop coefficient $\left(K_{\mathrm{c}}\right)$ is often used to estimate cropland ET ${ }^{14}$. The $K_{\mathrm{c}}$ reflects the crop species, its biological characteristics, yield, soil conditions, and fertilizer management ${ }^{15,16}$. Studying many crops, Pereira and Alves emphasized the necessity of calculating $K_{\mathrm{c}}$ under different climatic conditions ${ }^{17}$. Allen suggested that $K_{\mathrm{c}}$ can be calculated using large weighing lysimeters and local meteorological data ${ }^{18}$. Previous studies have been done about ET in flood-irrigated winter wheat. For example, Zhang estimated the $K_{\mathrm{c}}$ of flood-irrigated winter wheat on the North China Plain using the dual crop coefficient approach ${ }^{19}$. The authors reported that the $K_{\mathrm{c}}$ values were $0.12,1.15$, and 0.30 during the initial development, mid-season, and late-season stages, respectively. However, there are no reports about $K_{\mathrm{c}}$ in drip-irrigated winter wheat.

Drip-irrigated winter wheat production occurs at $5.07 \times 10^{5}$ ha in China's Xinjiang Uyghur Autonomous Region ${ }^{20}$. This makes the region one of the major wheat producing areas in China. However, the Xinjiang Region is a typical arid/semiarid area with low rainfall and humidity, high temperatures and humidity, strong winds, and long days. This has restricted regional agricultural develop- ment and grain output. Information about the ET and $K_{\mathrm{c}}$ of drip-irrigated winter wheat in Xinjiang Province is important for the sustainable use of water resources and economic development.

In this study, we used large weighing lysimeters to determine the effects of irrigation amount on the ET characteristics of drip-irrigated winter wheat. The specific objectives of this study were (1) to measure ET and $K_{\mathrm{c}}$ at different stages of the winter wheat growing season, (2) to investigate the factors affecting seasonal variation in $K_{\mathrm{c}}$, and (3) to provide useful information for optimizing drip irrigation of winter wheat.

\section{MATERIALS AND METHODS}

\section{Experimental site description}

The field experiment was carried out during two winter wheat seasons (Sept 2013-June 2014 and Sept 2014-June 2015) at the Water-Saving Irrigation Research Institute of Shihezi University, Xinjiang Province, China $\left(45^{\circ} 19^{\prime} \mathrm{N}, 86^{\circ} 03^{\prime} \mathrm{E}, 440 \mathrm{~m}\right.$ above sea level). During the 2013-2014 winter wheat growing season, the mean temperature was $3.7^{\circ} \mathrm{C}$, total radiation was $3435 \mathrm{MJ} / \mathrm{m}^{2}$, mean relative humidity was $62 \%$, total rainfall was $77 \mathrm{~mm}$, and total evaporation was $746 \mathrm{~mm}$ (Table 1). During the 2014-2015 winter wheat growing season, the mean temperature was $4.76^{\circ} \mathrm{C}$, total radiation was $3408 \mathrm{MJ} / \mathrm{m}^{2}$, mean relative humidity was $66 \%$, total rainfall was $72.3 \mathrm{~mm}$, and total evaporation was $720 \mathrm{~mm}$.

The soil is classified as a grey desert soil. The field capacity was $24 \%$ in 2013-2014 and $22 \%$ in $2014-2015$. The wilting point was $8 \%$ in 2013-2014 and 8\% in 2014-2015. The physico- 
Table 2 Selected soil physical and chemical properties (0-60 cm depth) in the experiment plots.

\begin{tabular}{lcc}
\hline Parameter & \multicolumn{2}{c}{ Value } \\
\cline { 2 - 3 } & $2013-2014$ & $2014-2015$ \\
\hline Clay (\%) & $19.5 \pm 1.8$ & $20.5 \pm 2.1$ \\
Silt (\%) & $36.8 \pm 2.2$ & $37.2 \pm 2.0$ \\
Sand (\%) & $41 \pm 2$ & $43 \pm 2$ \\
pH & $7.72 \pm 0.23$ & $7.52 \pm 0.34$ \\
Organic matter (mg/kg) & $27.2 \pm 1.4$ & $25.2 \pm 1.2$ \\
Alkaline-N (mg/kg) & $62.5 \pm 2.1$ & $60.5 \pm 1.9$ \\
Olsen-P (mg/kg) & $27.2 \pm 1.3$ & $25.2 \pm 1.1$ \\
Available K (mg/kg) & $343 \pm 11$ & $339 \pm 12$ \\
Field capacity (\%) & $23.6 \pm 1.5$ & $22.4 \pm 1.2$ \\
Wilting water content (\%) & $8.2 \pm 0.3$ & $7.9 \pm 0.2$ \\
Saturated volumetric & & \\
$\quad$ water content (\%) & $33.9 \pm 2.1$ & $33.7 \pm 1.6$ \\
\hline
\end{tabular}

chemical properties of the soil at the experimental sites were similar in both years (Table 2).

\section{Experiment materials and design}

The experiment included three irrigation amounts: $375 \mathrm{~mm}$ (D1), $600 \mathrm{~mm}$ (D2), and $750 \mathrm{~mm}$ (D3) (Table 3). The plots were drip-irrigated ten times during both growing seasons. Sixty $\mathrm{mm}$ of water was applied to each treatment on the day after sowing to ensure germination. Additional 35, 92, and $138 \mathrm{~mm}$ of water were applied in D1, D2, and D3, respectively, in November. After regreening in spring, the plots were irrigated once every $10 \mathrm{~d}$. On each day, the irrigation amounts in D1, D2, and D3 were 35,56 , and $69 \mathrm{~mm}$, respectively.

Winter wheat 'Xindong 43' (obtained from the Agricultural Reclamation Breeding Academy of Xinjiang Province) was sown on 25 Sept 2013 and on 30 Sept 2014. The wheat was harvested on 28 June 2014 and 27 June 2015. The row spacing $(15 \mathrm{~cm})$ and seeding rate (4.5 million seeds/ha) were the same in both cropping seasons. Fertilizer was applied at the following rates: $250 \mathrm{~kg} / \mathrm{ha} \mathrm{N}$ (urea), $250 \mathrm{~kg} / \mathrm{ha} \mathrm{P}_{2} \mathrm{O}_{5}$ (calcium superphosphate), $75 \mathrm{~kg} / \mathrm{ha} \mathrm{K}_{2} \mathrm{O}(\mathrm{KCl})$, and $30 \mathrm{~kg} / \mathrm{ha} \mathrm{ZnSO}_{4}$. The urea fertilizer was applied via drip irrigation in equal amounts (75 kg/ha N) in November and then at regreening, jointing, and heading. The other fertilizers were incorporated into the soil at sowing.

The drip tapes were manufactured by the Lüyuan Company (Beijing, China). There was $60 \mathrm{~cm}$ spacing (i.e., four wheat rows) between each drip tape (Fig. 1). The emitter discharge rate was $3.2 \mathrm{l} / \mathrm{h}$, the dripper spacing of $0.30 \mathrm{~m}$ was chosen in the actual production, the percentage of wetted
Table 3 Irrigation rates in the field experiment.

\begin{tabular}{|c|c|c|c|c|}
\hline \multirow[t]{2}{*}{ Year } & \multirow[t]{2}{*}{ Date } & \multicolumn{3}{|c|}{ Irrigation rate $(\mathrm{mm})$} \\
\hline & & $\mathrm{D} 1^{\dagger}$ & D2 & D3 \\
\hline \multirow[t]{10}{*}{ 2013-2014 } & $28 \mathrm{Sep}$ & 60 & 60 & 60 \\
\hline & 11 Nov & 35 & 92 & 138 \\
\hline & $28 \mathrm{Mar}$ & 35 & 56 & 69 \\
\hline & $7 \mathrm{Apr}$ & 35 & 56 & 69 \\
\hline & 17 Apr & 35 & 56 & 69 \\
\hline & 27 Apr & 35 & 56 & 69 \\
\hline & 7 May & 35 & 56 & 69 \\
\hline & 17 May & 35 & 56 & 69 \\
\hline & 27 May & 35 & 56 & 69 \\
\hline & 6 Jun & 35 & 56 & 69 \\
\hline \multirow[t]{10}{*}{ 2014-2015 } & 1 Oct & 60 & 60 & 60 \\
\hline & $4 \mathrm{Nov}$ & 35 & 92 & 138 \\
\hline & 27 Mar & 35 & 56 & 69 \\
\hline & $6 \mathrm{Apr}$ & 35 & 56 & 69 \\
\hline & $16 \mathrm{Apr}$ & 35 & 56 & 69 \\
\hline & $26 \mathrm{Apr}$ & 35 & 56 & 69 \\
\hline & 6 May & 35 & 56 & 69 \\
\hline & 16 May & 35 & 56 & 69 \\
\hline & 26 May & 35 & 56 & 69 \\
\hline & 5 Jun & 35 & 56 & 69 \\
\hline
\end{tabular}

$\dagger$ Treatments.

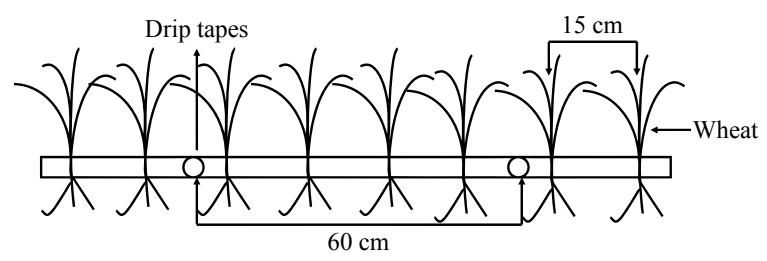

Fig. 1 Sketch map showing the spacing between wheat rows and between drip tapes.

area is $70 \%$ in drip irrigation. The amount of irrigation applied to each plot was controlled with a water meter. The plots were $5 \mathrm{~m} \times 8 \mathrm{~m}$. The plots were arranged in a randomized complete block design with three replicates. Impermeable plastic membrane was buried between the plots to prevent lateral water movement.

\section{Measurements}

Evapotranspiration: ET was measured using large weighing lysimeters $(2 \mathrm{~m}$ long $\times 2 \mathrm{~m}$ wide $\times 2.3 \mathrm{~m}$ deep, Xi'an New Clear Water Environment Technology Co., LTD., Xi'an, China) that were installed in each plot. The upper edge of each lysimeter was $10 \mathrm{~cm}$ above the soil surface. The height of the soil surface was the same inside and outside the lysimeters. The weighing system consisted of 
a high-precision, counter-weighted platform scale. The scale could detect moisture changes between 0 and $3000 \mathrm{~kg}$ with accuracy of $\pm 0.2 \mathrm{~kg}(0.05 \mathrm{~mm})$. The abnormal values were automatically filtered by the software and then the data were converted to ET with a calibration coefficient. Lysimeter performance was checked once at each growth stage. Data collected during rainfall and irrigation events were eliminated. The measurements were made automatically each hour.

Reference evapotranspiration: $\mathrm{ET}_{0}$ was determined with an $\mathrm{ET}_{0}$ calculator which was based on the Penman-Monteith equation ${ }^{21}$. This equation, which is recommended by the FAO, is the most general and widely used method for calculating daily reference $\mathrm{ET}_{0}{ }^{22}$. The inputs for the calculator [maximum air temperature $\left(T_{\max }\right)$, minimum air temperature $\left(T_{\min }\right)$, maximum relative humidity $\left(\mathrm{RH}_{\max }\right)$, minimum relative humidity $\left(\mathrm{RH}_{\text {min }}\right)$, sunshine hours $(n / N)$ and wind speed at a height of $2 \mathrm{~m}\left(u_{2}\right)$ ] were based on weather data collected between 2013 and 2015 at the Shihezi Meteorological Observatory station.

Soil evaporation: daily soil evaporation was measured with four micro-lysimeters that were placed between two wheat rows. The microlysimeters contained small isolated volumes of bare soil mounted flush with or slightly above the soil surface $^{9}$. Specifically, the micro-lysimeters consisted of two polyvinyl chloride pipes $(20 \mathrm{~cm}$ high). The larger external pipe $(11 \mathrm{~cm}$ diam $)$ was installed vertically in the soil profile (Fig. 1). The smaller internal pipe $(9 \mathrm{~cm}$ diam) was filled with soil and then lowered into the larger pipe so that the soil surface inside the small pipe was level with that outside the large pipe. The small (i.e., inner) pipes were removed from the larger pipes daily (sometimes more frequently) and then weighed with an electronic balance $(0.01 \mathrm{~kg}$ precision) to determine water loss. The small pipes were then placed back inside the large pipes. Evaporation was calculated using the formula $E=\Delta W / \pi r^{2}$ where $\Delta W$ is the change in weight of the micro-lysimeter per unit time and $r$ is the inner diameter of the small pipe (i.e., micro-lysimeter barrel). Soil $E$ in each plot was calculated as the average of the four microlysimeters.

Soil moisture: soil water content was measured using Decagon 5 TE soil moisture probes (Decagon Device Inc. Washington State, USA). The probes were installed in each plot at the $20,40,60,100$, and $150 \mathrm{~cm}$ depths. The soil water content was measured each day from sowing to maturity.
Leaf area, predicted yield, and aboveground biomass: Green leaf area was measured with an LI-3100 leaf area meter (LI COR Inc., Lincoln, NE, USA). The leaf area index (LAI) was calculated by multiplying the leaf area ( $\mathrm{m}^{2} /$ plant) by the plant population (plant number $/ \mathrm{m}^{2}$ ). Samples were collected once every seven days. The samples were dried in an oven at $75^{\circ} \mathrm{C}$ for at least $72 \mathrm{~h}$ and then the weights of the leaf blades, stems, and panicles were measured. At maturity, $1 \mathrm{~m}^{2}$ areas from each plot were harvested to calculate the grain yield and harvest index (the ratio of the filled spikelet weight to the total aboveground biomass).

Water use efficiency: WUE was calculated by dividing grain yield by ET (i.e., WUE $=Y / E T$ ).

Meteorological data: the meteorological data (i.e., temperature, humidity, wind speed, relative humidity, and soil temperature) were downloaded from the website of the Shihezi Meteorological Observatory. The experiment site was located $100 \mathrm{~m}$ from the observatory.

\section{Statistical analysis}

The data were analysed using the generalized linear model procedure (SPSS version 16.0). Differences between means were compared using Fisher's least-significant-difference test at the $5 \%$ probability level.

\section{RESULTS}

\section{Yield, WUE, and harvest index}

The number of panicles per hectare, grain number per spike, 1000 grain weight, and yield increased as irrigation amount increased in both cropping seasons (Table 4). The differences between D2 and D3 were not significant in either growing season. In contrast, the means of both treatments were significantly greater than those of D1. The yields of D2 and D3 were 1.25-1.32 times those of D1. WUE decreased as the amount of irrigation water increased. Depending on the cropping season, WUE in D1 was 1.14-1.16 times that in D2, and 1.27-1.3 times that in D3. The harvest index increased as irrigation amount increased. Differences between D2 and D3 were not significant in either growing season. The harvest indexes of D2 and D3 were 1.26-1.42 times that of D1.

\section{Soil water}

The effect of irrigation on volumetric soil water content decreased as soil depth increased (Fig. 2). During winter, the volumetric soil water content did 
Table 4 Winter wheat yield, water use efficiency (WUE), and harvest index as affected by drip irrigation amount.

\begin{tabular}{lccccccc}
\hline $\begin{array}{l}\text { Growing } \\
\text { season }\end{array}$ & Treatment & $\begin{array}{c}\text { Panicles } \\
\left(\times 10^{4} \mathrm{ha}^{-1}\right)\end{array}$ & $\begin{array}{c}\text { Grain number } \\
\text { per spike }\end{array}$ & $\begin{array}{l}\text { 1000-grain } \\
\text { weight }(\mathrm{g})\end{array}$ & $\begin{array}{c}\text { Yield } \\
(\mathrm{kg} / \mathrm{ha})\end{array}$ & $\begin{array}{c}\text { WUE } \\
\left(\mathrm{kg} / \mathrm{m}^{3}\right)\end{array}$ & Harvest index \\
\hline $2013-2014$ & D1 & $515 \pm 13^{\mathrm{b}}$ & $39.2 \pm 1.8^{\mathrm{b}}$ & $43.7 \pm 1.1^{\mathrm{b}}$ & $7820 \pm 260^{\mathrm{b}}$ & $1.84 \pm 0.06^{\mathrm{a}}$ & $0.33 \pm 0.03^{\mathrm{b}}$ \\
& D2 & $585 \pm 10^{\mathrm{a}}$ & $47.6 \pm 1.5^{\mathrm{a}}$ & $50.4 \pm 0.9^{\mathrm{a}}$ & $9880 \pm 380^{\mathrm{a}}$ & $1.59 \pm 0.06^{\mathrm{b}}$ & $0.43 \pm 0.02^{\mathrm{a}}$ \\
& D3 & $598 \pm 6^{\mathrm{a}}$ & $49.6 \pm 1.2^{\mathrm{a}}$ & $52.4 \pm 1.9^{\mathrm{a}}$ & $10360 \pm 390^{\mathrm{a}}$ & $1.41 \pm 0.05^{\mathrm{b}}$ & $0.47 \pm 0.03^{\mathrm{a}}$ \\
$2014-2015$ & D1 & $561 \pm 13^{\mathrm{b}}$ & $38.2 \pm 1.1^{\mathrm{b}}$ & $40.1 \pm 1.6^{\mathrm{b}}$ & $8180 \pm 380^{\mathrm{b}}$ & $1.91 \pm 0.09^{\mathrm{a}}$ & $0.35 \pm 0.02^{\mathrm{b}}$ \\
& D2 & $612 \pm 12^{\mathrm{a}}$ & $44.8 \pm 1.4^{\mathrm{a}}$ & $49.8 \pm 1.7^{\mathrm{a}}$ & $10240 \pm 770^{\mathrm{a}}$ & $1.67 \pm 0.13^{\mathrm{ab}}$ & $0.44 \pm 0.02^{\mathrm{a}}$ \\
& D3 & $621 \pm 8^{\mathrm{a}}$ & $46.4 \pm 1.2^{\mathrm{a}}$ & $51.2 \pm 1.9^{\mathrm{a}}$ & $10680 \pm 640^{\mathrm{a}}$ & $1.50 \pm 0.09^{\mathrm{b}}$ & $0.46 \pm 0.01^{\mathrm{a}}$ \\
\hline
\end{tabular}

Values are means \pm SD. Means within a column followed by different lowercase letters are significantly different at $p<0.05$. Abbreviations: D1, $375 \mathrm{~mm}$; D2, $600 \mathrm{~mm}$; D3, $750 \mathrm{~mm}$.

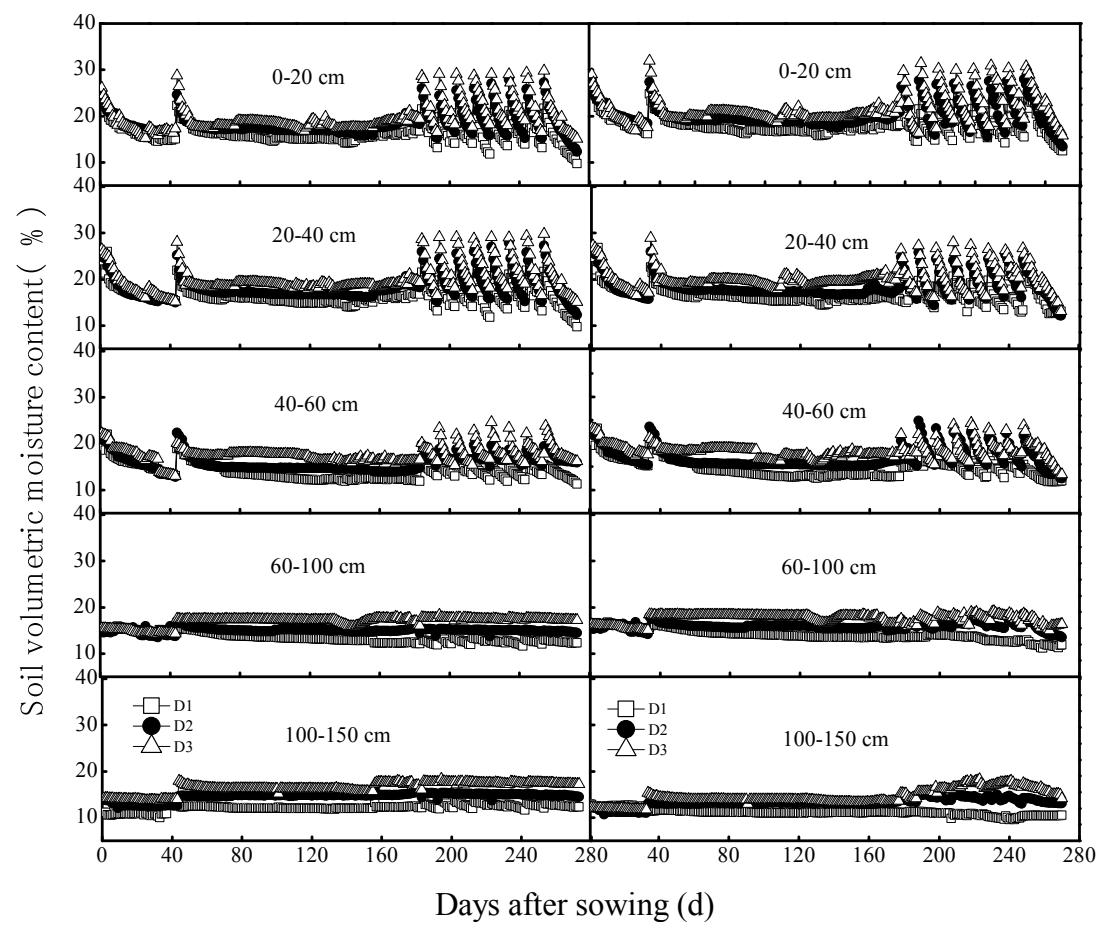

Fig. 2 Temporal changes in volumetric water content at different soil depths as affected by drip irrigation amount. Measurements were made during the 2013-2014 and 2014-2015 winter wheat growing seasons. Abbreviations: D1, $375 \mathrm{~mm}$; D2, $600 \mathrm{~mm}$; D3, $750 \mathrm{~mm}$.

not differ significantly among the three treatments. After regreening, the volumetric water content in the $0-20 \mathrm{~cm}$ depth of $\mathrm{D} 1$ increased from $15 \%$ before irrigation to $24 \%$ after irrigation. An increase of similar magnitude was observed in the $20-40 \mathrm{~cm}$ depth. Smaller increases were observed in the $40-60 \mathrm{~cm}$ depth (from $11 \%$ before irrigation to $14 \%$ after irrigation) and the $60-100 \mathrm{~cm}$ depth (from $11 \%$ before irrigation to $12 \%$ after irrigation). Irrigation had almost no effect on volumetric water content in the 100-150 cm depth. This pattern was also observed in D2 and D3; however the difference in soil water content before and after irrigation increased as irrigation amount increased. From regreening to maturity, the average soil volumetric water in the $0-20 \mathrm{~cm}$ depth was $27 \%$ in D3, $23 \%$ in $\mathrm{D} 2$, and $18 \%$ in $\mathrm{D} 1$. In the $20-40 \mathrm{~cm}$ depth, the average volumetric content was $24 \%$ in D3, $19 \%$ in D2, and $14 \%$ in D1.

\section{Evapotranspiration}

Temporal changes in actual daily ET showed similar patterns in all three treatments in both cropping seasons (Fig. 3). Daily ET rates decreased slowly between 0 and 160 days after sowing (DAS) and then more rapidly as air temperature decreased in 


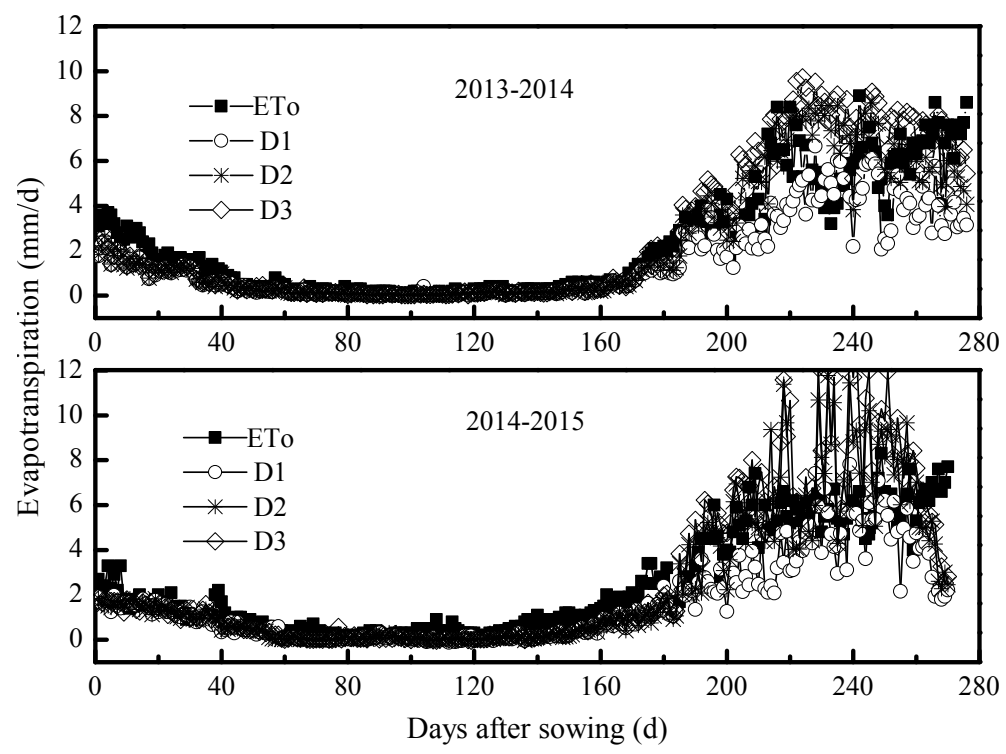

Fig. 3 Daily evapotranspiration rates as affected by drip irrigation amount in the 2013-2014 and 2014-2015 winter wheat growing seasons. Abbreviations: $\mathrm{ET}_{0}$, reference evapotranspiration; D1, $375 \mathrm{~mm}$; D2, $600 \mathrm{~mm}$; D3, 750 mm.
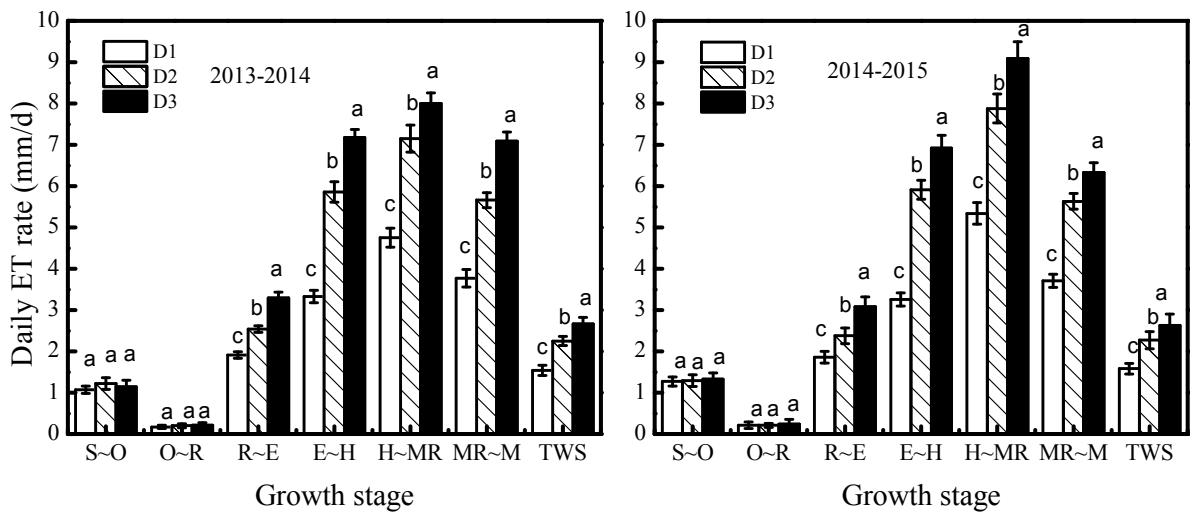

Fig. 4 Average daily evapotranspiration rates at different winter wheat growth stages as affected by drip irrigation amount. Measurements were made during the 2013-2014 and 2014-2015 growing seasons. Error bars represent standard deviation $(n=3)$. Bars with different lowercase letters are significantly different at $p<0.05$. Abbreviations: D1, $375 \mathrm{~mm}$; D2, $600 \mathrm{~mm}$; D3, $750 \mathrm{~mm}$; S O, sowing-overwinter; O R, overwinter-regreening; R E, regreeningelongation; $\mathrm{E} \sim \mathrm{H}$, elongation-heading; $\mathrm{H} \sim \mathrm{MR}$, heading-milk ripening; $\mathrm{MR} \sim \mathrm{M}$, milk ripening-maturity; TWS, the entire winter wheat growing season.

late fall and early winter. Daily ET rates were lowest during the overwinter period. Daily ET rates rapidly increased from regreening to milk ripening and then gradually declined during late grain filling. Daily ET rates decreased in the order D3 $>$ D2 $>$ D1. The ET and $\mathrm{ET}_{0}$ showed the same pattern with time.

Average daily ET rates during different growth stages were calculated by dividing total ET during the growth stage by the number of days. Similar patterns were observed during both growing seasons (Fig. 4). Average daily ET rates were lowest during sowing-overwinter and overwinter-regreening. Furthermore, there was no significant difference among the treatments during those two periods. Average daily ET rates decreased significantly in the order D3 $>$ D2 $>$ D1 after regreening. Average daily ET rates were greatest during heading-milk ripening, averaging $8.53 \mathrm{~mm} / \mathrm{d}$ in D3, $7.52 \mathrm{~mm} / \mathrm{d}$ in D2, and $5.05 \mathrm{~mm} / \mathrm{d}$ in D1. The second highest rates were during elongation-heading, averaging $7.05 \mathrm{~mm} / \mathrm{d}$ in D3, $5.89 \mathrm{~mm} / \mathrm{d}$ in D2, and $3.30 \mathrm{~mm} / \mathrm{d}$ in D1. The milk ripening-maturity and regreening-elongation 


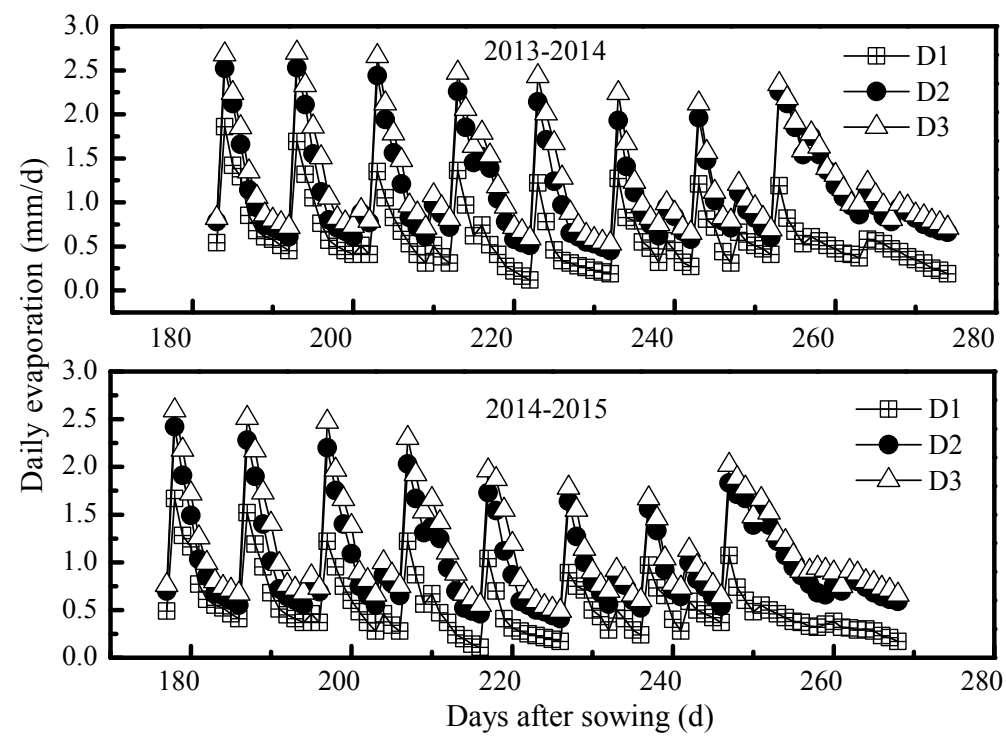

Fig. 5 Daily soil evaporation rates as affected by drip irrigation amount in the 2013-2014 and 2014-2015 winter wheat growing seasons. Abbreviations: D1, $375 \mathrm{~mm}$; D2, $600 \mathrm{~mm}$; D3, $750 \mathrm{~mm}$.

stages had the third and fourth highest rates, respectively. Averaged across both growing seasons, average daily ET rates decreased significantly in the order D3 $(2.64 \mathrm{~mm} / \mathrm{d})>$ D2 $(2.26 \mathrm{~mm} / \mathrm{d})>$ D1 $(1.55 \mathrm{~mm} / \mathrm{d})$.

\section{Soil evaporation under the drip irrigation}

Daily soil $E$ rates in the drip-irrigated winter wheat are shown in Fig. 5. Daily soil $E$ rates decreased in the order D3 $>$ D2 $>$ D1. However, the temporal changes in daily soil $E$ were generally the same, regardless of water amount. Specifically, daily soil $E$ rates increased to 0.5 and $3.0 \mathrm{~mm} / \mathrm{d}$ immediately after irrigation. The $E$ rates decreased rapidly to $<1.0 \mathrm{~mm} / \mathrm{d}$ within four days after irrigation and then levelled off.

Evaporation accounted for $75 \%$ of ET during sowing-overwinter and $70 \%$ of ET during overwinter-regreening (Table 5). This is because (i) transpiration rates and groundcover were both low, and (ii) the water content of the surface soil was great enough to respond to the evaporative demand. During regreening-elongation, E/ET decreased to an average of $29 \%$ in D1, $40 \%$ in D2, and $42 \%$ in D3. During elongation-heading, E/ET was $16 \%$ in D1, $20 \%$ in D2, and 20\% in D3. Transpiration reached a maximum during heading-milk ripening, with $E / E T$ decreasing to $8 \%$ in $\mathrm{D} 1,11 \%$ in $\mathrm{D} 2$, and $12 \%$ in D3. The wheat leaves began to senesce after milk ripening and groundcover declined. This caused E/ET to increase. Averaging both growing seasons,

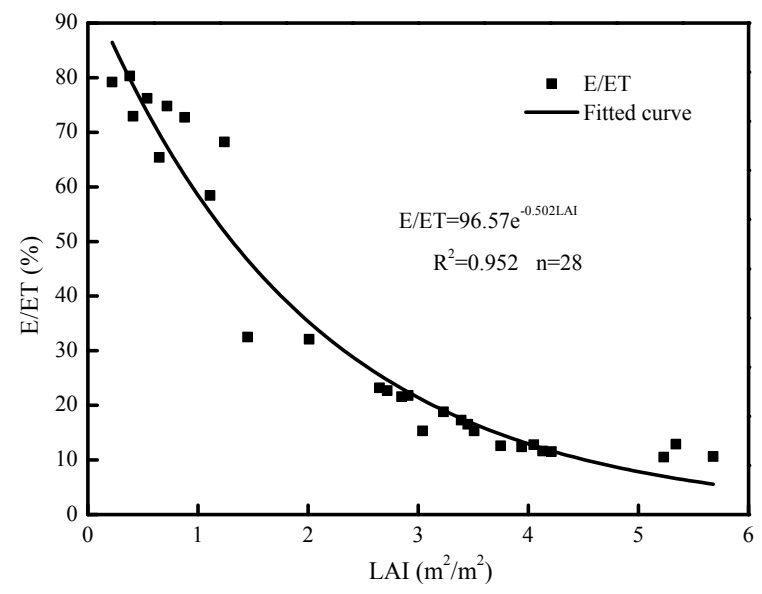

Fig. 6 Relationship between the evaporation/evapotranspiration ratio (E/ET) and the leaf area index (LAI) during two winter wheat growing seasons.

ET was $427 \mathrm{~mm}$ in D1, $617 \mathrm{~mm}$ in D2, and $722 \mathrm{~mm}$ in D3. The E/ET values averaged $26 \%$ in D1, $27 \%$ in $\mathrm{D} 2$, and $28 \%$ in $\mathrm{D} 3$.

Fig. 6 shows that E/ET decreased rapidly as LAI increased while the canopy was still developing (i.e., LAI < 3). This is because transpiration rates and groundcover both increased as the canopy grew. The decrease in E/ET was not as rapid when LAI $>3$. The leaf area became stable resulting in a relatively stable $E$ and transpiration; hence $E / E T$ decreased slowly as LAI increased. The relationship 
Table 5 Evaporation (E), evapotranspiration (ET) and the E/ET ratio as affected by irrigation amount in the 2013-2014 and 2014-2015 winter wheat growing seasons.

\begin{tabular}{|c|c|c|c|c|c|c|c|c|c|}
\hline Year & Treatment & Variate & $S \sim O^{*}$ & $\mathrm{O} \sim \mathrm{R}$ & $\mathrm{R} \sim \mathrm{E}$ & $\mathrm{E} \sim \mathrm{H}$ & $\mathrm{H} \sim \mathrm{MR}$ & $\mathrm{MR} \sim \mathrm{M}$ & TWS \\
\hline \multirow[t]{9}{*}{$2013-2014$} & \multirow[t]{3}{*}{$\mathrm{D} 1^{\dagger}$} & $E(\mathrm{~mm})$ & 39.6 & 15.5 & 15.6 & 13.5 & 10.8 & 12.5 & 107.5 \\
\hline & & ET (mm) & 52.4 & 21.3 & 53.5 & 86.6 & 132.9 & 79.1 & 425.9 \\
\hline & & E/ET (\%) & 75.6 & 72.8 & 29.2 & 15.6 & 8.1 & 14.5 & 25.2 \\
\hline & \multirow[t]{3}{*}{ D2 } & $E(\mathrm{~mm})$ & 42.1 & 18.8 & 28.1 & 31.5 & 19.6 & 23.8 & 163.9 \\
\hline & & $\mathrm{ET}(\mathrm{mm})$ & 55 & 24.7 & 71 & 152.5 & 200.2 & 118.9 & 620.4 \\
\hline & & E/ET (\%) & 76.5 & 76.1 & 39.6 & 20.7 & 9.8 & 20 & 26.4 \\
\hline & \multirow[t]{3}{*}{ D3 } & $E(\mathrm{~mm})$ & 44.5 & 20.4 & 38.5 & 36.7 & 25.9 & 39.9 & 201.9 \\
\hline & & ET (mm) & 56 & 25.6 & 92 & 186.6 & 224.1 & 148.8 & 733.2 \\
\hline & & E/ET (\%) & 79.5 & 79.7 & 41.8 & 19.7 & 11.6 & 24.1 & 27.5 \\
\hline \multirow[t]{9}{*}{ 2014-2015 } & \multirow[t]{3}{*}{ D1 } & $E(\mathrm{~mm})$ & 40.8 & 18.2 & 16.1 & 13.8 & 11.9 & 12.5 & 113.3 \\
\hline & & ET (mm) & 54.6 & 26.2 & 55.8 & 81.6 & 138.8 & 70.4 & 427.4 \\
\hline & & E/ET (\%) & 74.7 & 69.5 & 28.9 & 16.9 & 8.6 & 17.8 & 26.5 \\
\hline & \multirow[t]{3}{*}{ D2 } & $E(\mathrm{~mm})$ & 42.3 & 19.3 & 29.4 & 27.8 & 23.6 & 28.4 & 170.8 \\
\hline & & ET (mm) & 55.6 & 26.7 & 71.4 & 147.6 & 205 & 106.9 & 613.1 \\
\hline & & E/ET (\%) & 76.1 & 72.2 & 41.1 & 18.8 & 11.5 & 26.6 & 27.8 \\
\hline & \multirow[t]{3}{*}{ D3 } & $E(\mathrm{~mm})$ & 43.5 & 20.6 & 39.8 & 36.1 & 28.4 & 32.8 & 201.2 \\
\hline & & ET (mm) & 57 & 30.2 & 92.4 & 173.1 & 236.4 & 120.2 & 711.3 \\
\hline & & E/ET (\%) & 76.3 & 68.2 & 43.1 & 20.9 & 12 & 27.3 & 28.3 \\
\hline
\end{tabular}

Table 6 Crop coefficient $\left(K_{\mathrm{c}}\right)$ in the D2 treatment (600 mm irrigation water) during the 2013-2014 and 2014-2015 winter wheat growing seasons.

\begin{tabular}{lcccccccc}
\hline Year & Variable & $\mathrm{S} \sim \mathrm{O}^{\dagger}$ & $\mathrm{O} \sim \mathrm{R}$ & $\mathrm{R} \sim \mathrm{E}$ & $\mathrm{E} \sim \mathrm{H}$ & $\mathrm{H} \sim \mathrm{MR}$ & $\mathrm{MR} \sim \mathrm{M}$ & $\mathrm{TWS}$ \\
\hline 2013-2014 & Days & 49 & 124 & 28 & 26 & 28 & 21 & 276 \\
& $\mathrm{ET}(\mathrm{mm})$ & 55 & 22.7 & 71 & 157.4 & 195.5 & 118.9 & 620.4 \\
& $\mathrm{ET}_{0}(\mathrm{~mm})$ & 87.5 & 40.6 & 78.7 & 137.2 & 151.8 & 145.2 & 642.1 \\
& $K_{\mathrm{c}}$ & 0.63 & 0.56 & 0.9 & 1.08 & 1.34 & 0.82 & 0.97 \\
$2014-2015$ & Days & 43 & 127 & 30 & 25 & 26 & 19 & 270 \\
& $\mathrm{ET} \mathrm{(mm)}$ & 55.6 & 26.7 & 71.39 & 147.6 & 204.95 & 106.9 & 613.1 \\
& $\mathrm{ET}_{0}(\mathrm{~mm})$ & 75.9 & 78.1 & 96.5 & 133.7 & 151.8 & 114.1 & 650.1 \\
& $K_{\mathrm{c}}$ & 0.77 & 0.34 & 0.74 & 1.1 & 1.35 & 0.94 & 0.94 \\
\hline
\end{tabular}

${ }^{\dagger} \mathrm{S} \sim \mathrm{O}$, sowing-overwinter; $\mathrm{O} \sim \mathrm{R}$, overwinter-regreening; $\mathrm{R} \sim \mathrm{E}$, regreening-elongation; $\mathrm{E} \sim \mathrm{H}$, elongation-heading; $\mathrm{H} \sim \mathrm{MR}$, heading-milk ripening; $\mathrm{MR} \sim \mathrm{M}$, milk ripening-maturity; TWS, the entire winter wheat growing season.

between $E$ /ET and LAI was best described with an exponential function (i.e., $E / E T=96.57 \mathrm{e}^{-0.502 \mathrm{LAI}}$, $\left.R^{2}=0.952\right)$. The $R^{2}$ values were $>0.95$.

\section{Crop coefficient of the drip-irrigated winter wheat}

The $K_{\mathrm{c}}$ is mainly affected by the characteristics of the specific crop. Climate, growing conditions, and growth stage also influence $K_{\mathrm{c}}$. When yield, WUE, and harvest index were considered, D2 was best among the treatments in this study. Hence the $K_{\mathrm{c}}$ of drip-irrigated winter wheat was calculated using the actual $\mathrm{ET}$ and the $\mathrm{ET}_{0}$ of $\mathrm{D} 2$. The $K_{\mathrm{c}}$ was least during the sowing-overwinter and the overwinter-regreening stages. The $K_{\mathrm{c}}$ was greatest during heading-milk ripening. Averaged across both growing seasons, $K_{\mathrm{c}}$ was 0.70 during sowing-overwinter, 0.45 during overwinter-regreening, 0.82 during regreeningelongation, 1.09 during elongation-heading, 1.35 during heading-milk ripening, and 0.88 during milk ripening-maturity (Table 6). Averaged across all stages, the $K_{\mathrm{c}}$ was 0.96 for drip-irrigated winter 


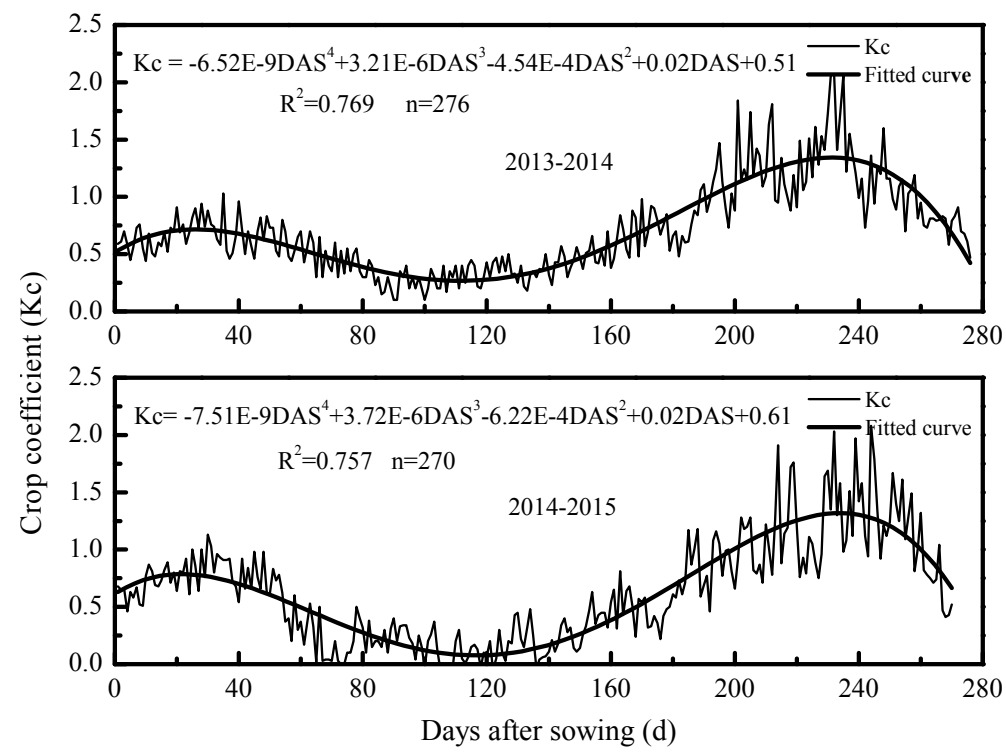

Fig. 7 Temporal changes in the crop coefficient $\left(K_{c}\right)$ during the 2013-2014 and 2014-2015 winter wheat growing seasons.

wheat in Xinjiang Province.

A fourth-order regression curve $\left(K_{\mathrm{c}}=a_{4} \mathrm{DAS}^{4}+\right.$ $a_{3} \mathrm{DAS}^{3}+a_{2} \mathrm{DAS}^{2}+a_{1} \mathrm{DAS}+a_{0}$ ) was fitted to the daily $K_{\mathrm{c}}$ values across each growing season (Fig. 7). The $K_{\mathrm{c}}$ values increased to a maximum 35 DAS (tillering) and then decreased during overwintering. The $K_{\mathrm{c}}$ values increased again in the spring and reached a maximum 230 DAS (grain filling).

The relationship between $K_{\mathrm{c}}$ and LAI is shown in Fig. 8. The $K_{\mathrm{c}}$ values increased as LAI increased. The increases in $K_{\mathrm{c}}$ were the largest when LAI was $<1.5$. The increases were smaller when LAI was $>3$. Regression analysis showed that the relationship between $K_{\mathrm{c}}$ and LAI was best described by a logarithmic function, i.e. $K_{\mathrm{c}}=b \ln (\mathrm{LAI})+c$.

\section{DISCUSSION}

The availability of water for irrigation is limited in many arid and semiarid areas. Because of this, the goal of irrigation management should not be to maximize yield. Instead, the purpose should be to find the optimum benefit when considering yield, WUE, and harvest index.

In a previous survey, we observed large differences in irrigation rate among different locations in northern Xinjiang Province. The irrigation rates generally ranged between 400 and $750 \mathrm{~mm}$. There were also large differences in the amount of irrigation water applied during the sowing-overwinter period. In some locations, farmers applied $35 \mathrm{~mm}$ irrigation water whereas in other areas farmers ap- plied 92 or $138 \mathrm{~mm}$. Overall, there was no standard. The irrigation rates in this study were chosen to represent the variation in field practices in northern Xinjiang Province.

Averaged across both growing seasons, ET was $427 \mathrm{~mm}$ in D1, $617 \mathrm{~mm}$ in D2, and $722 \mathrm{~mm}$ in D3. Total ET varied significantly among treatments and generally increased as irrigation amount increased. These results were consistent with studies involving sprinkler irrigation and flood irrigation ${ }^{23,24}$. Rainfall and irrigation significantly influence daily ET ${ }^{25}$. The temporal changes in ET and $\mathrm{ET}_{0}$ were the same in this region (Fig. 3), which is consistent with the results of the FAO. In addition, WUE declined as drip irrigation amount increased (Table 4). The harvest index and yield increased as irrigation amount increased; however, the differences between D2 and D3 were not significant. Based on these results, we conclude that D2 was the best irrigation amount for this region.

When yield, WUE, and harvest index were considered, the optimum ET was $613-620 \mathrm{~mm}$ (Table 5). This value was slightly greater than the values reported by Wohlfahrt and $\mathrm{Lei}^{26,27}$. The differences in optimum ET can be attributed to differences in climate among experiment sites. In Xinjiang Province, average temperatures are high, relative humidity is low, winds are strong, and days are long. As a result $E$ and ET rates are greater here than in other, less arid regions. The maximum daily ET rates were observed during heading-milk 

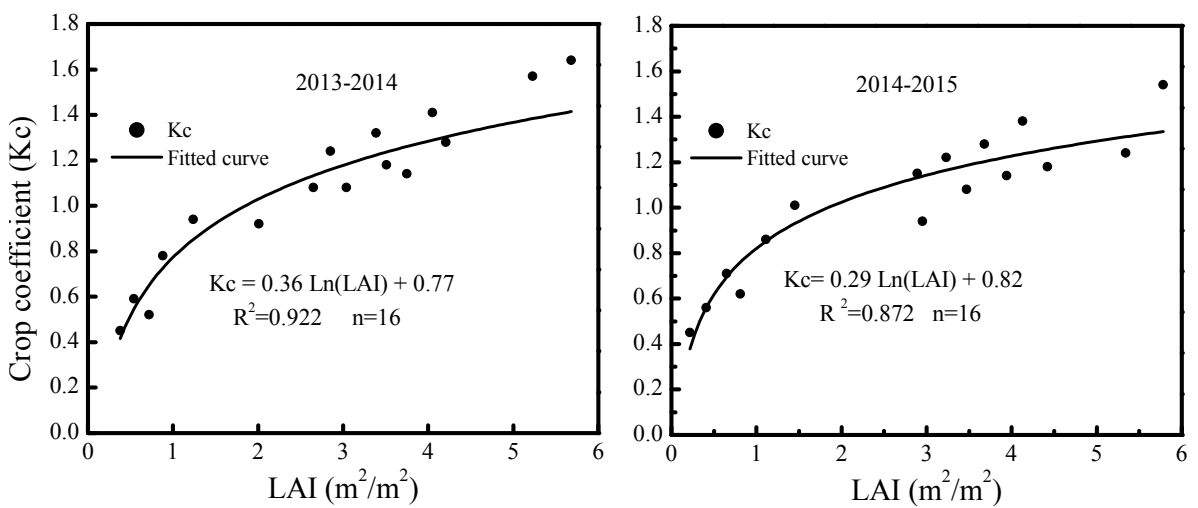

Fig. 8 Relationship between crop coefficient $\left(K_{\mathrm{c}}\right)$ and leaf area index (LAI) in the 2013-2014 and 2014-2015 winter wheat growing seasons.

ripening (Fig. 4., $5.05 \mathrm{~mm} / \mathrm{d}$ in D1, $7.52 \mathrm{~mm} / \mathrm{d}$ in $\mathrm{D} 2$, and $8.53 \mathrm{~mm} / \mathrm{d}$ in $\mathrm{D} 3$ ). The results indicate this is a water sensitive period. Wei observed that maximum daily ET $(9.35 \mathrm{~mm} / \mathrm{d})$ occurred $228-238$ DAS for winter wheat in Daxing, Beijing ${ }^{28}$. Research indicates that $80-90 \%$ of winter wheat roots are in the $0-60 \mathrm{~cm}$ depth ${ }^{29}$. The soil water content in the $0-40 \mathrm{~cm}$ depth varied significantly in all three treatments (Fig. 2). This indicates that drip irrigation was able to prevent water loss from soil evaporation when evaporative demand was high.

Unlike transpiration, $E$ does not directly affect crop yield. Controlling $E$ is important for increasing WUE and for conserving irrigation water. Many scholars have studied evaporation. Sun reported that $E /$ ET ranged from $31.3-37 \%$ in conventionally irrigated winter wheat in the North China Plain ${ }^{30}$. Similarly, Sadras and Rodriguez observed that $E$ /ET ranged from $30-35 \%$ in a flood irrigated wheat field in eastern Australia ${ }^{31}$. Our results showed that when averaged across the entire growing season, $E$ accounted for $26-28 \%$ of ET under drip irrigation (Table 5). These values were less than those reported in previous studies. Higher $E$ rates may occur under traditional irrigation practices because the entire soil surface is wet. In contrast, only part of the soil surface is wet under drip irrigation. Soil $E$ rates increased to 0.5 and $3.0 \mathrm{~mm} / \mathrm{d}$ immediately after drip irrigation. Evaporation rates decreased during the next four days and then levelled out at about $0.5 \mathrm{~mm} / \mathrm{d}$ (Fig. 5). When the soil water supply can meet the transpiration needs of crops, the $E$ /ET ratio is mainly affected by LAI. An exponential equation $\left(R^{2}>0.95\right)$ expressed the relation between $E /$ ET and LAI. The $E /$ ET values decreased rapidly until LAI reached 3.0 and then less rapidly after that. Hence applying larger amounts of wa- ter less frequently could reduce evaporation and increase irrigation WUE in drip-irrigated systems in arid areas.

The $K_{\mathrm{c}}$ is an important parameter for irrigation management. In this study, the $K_{\mathrm{c}}$ values were 0.7 shortly after sowing (Table 6 ). The $K_{\mathrm{c}}$ values declined to a minimum (0.45) during the overwinter period. The $K_{\mathrm{c}}$ values increased to a maximum (1.35) at heading-milk ripening, before decreasing again as the wheat ripened. The $K_{\mathrm{c}}$ averaged 0.96 across the entire growing season. In the FAO Irrigation and Drainage Paper 56, the $K_{\mathrm{c}}$ value was a minimum $(0.4-0.6)$ at both the beginning and ending of the winter wheat growing season ${ }^{22}$. The maximum value of $K_{\mathrm{c}}(1.15-1.2)$ was observed during the middle of the growing season, when LAI was greatest. The maximum $K_{\mathrm{c}}$ values in our study were greater than those in the FAO Paper. The $K_{\mathrm{c}}$ is determined by both ET and $\mathrm{ET}_{0}$. The LAI of the winter wheat is maximum at the heading-milk ripening stage; hence $E$ may have little influence on potential ET. High evaporative demand affects not only $\mathrm{ET}_{0}$ but also ET. Also, the characteristics of crop variety and the form of irrigation can also have greatly influence $K_{\mathrm{c}}$. The variation in $K_{\mathrm{c}}$ values can be shown as a function of days after sowing ${ }^{32}$. The relationship between $K_{\mathrm{c}}$ and days after sowing was fitted to a fourth-order polynomial equation $\left(R^{2}>\right.$ $0.75)$. This equation will be useful for estimating crop water use by drip-irrigated winter wheat in arid regions. Daily $K_{\mathrm{c}}$ values exhibited a bimodal pattern with peaks about 35 and 230 days after sowing (Fig. 7).

\section{CONCLUSIONS}

Our results indicate that $600 \mathrm{~mm}$ irrigation was optimum for drip-irrigated winter wheat production 
in Xinjiang. The $K_{\mathrm{c}}$ value was 0.96 across the entire growing season. $E$ was about $26-28 \%$ of the winter wheat ET during the entire season. A relatively large irrigation quota and low irrigation frequency may be considered for reducing $E$. Similar management practices should be applicable in other arid or semiarid areas.

Acknowledgements: This work was supported by the Chinese National Natural Science Fund (grant no: 31160260), National High-Tech Research and Development Projects (863) of China (grant no: 2011AA100508). We are grateful for the support and assistance of Professor Fuyu $\mathrm{Ma}$ and the other authors. We thank Dr William J. Gale (College of Agriculture, Shihezi University, China) for critical reading and professional editing of the manuscript.

\section{REFERENCES}

1. Bhunia SR, Verma IM, Arif M, Gochar R, Sharma NC (2015) Effect of crop geometry, drip irrigation and bio-regulator on growth, yield and water use efficiency of wheat (Triticum aestivum L.). Int $J$ Agr Sci 11, 45-9.

2. Rana G, Katerji N (2000) Measurement and estimation of actual evapotranspiration in the field under Mediterranean climate: a review. Eur J Agron 13, 125-53.

3. Ding R, Kang S, Li F, Zhang Y, Tong L (2013) Evapotranspiration measurement and estimation using modified Priestley-Taylor model in an irrigated maize field with mulching. Agr Forest Meteorol 168, 140-8.

4. Yan H, Oue H (2011) Application of the two-layer model for predicting transpiration from the rice canopy and water surface evaporation beneath the canopy. J Agr Meteorol 67, 89-97.

5. Kang SZ, Su XL, Tong L, Zhang JH, Zhang L, Davies WJ (2008) A warning from an ancient oasis: intensive human activities are leading to potential ecological and social catastrophe. Int J Sustain Dev World Ecol 15, 440-7.

6. Yan HF, Oue H, Zhang C (2012) Predicting water surface evaporation in the paddy field by solving energy balance equation beneath the rice canopy. Paddy Water Environ 10, 121-7.

7. Zhang C, Yan HF, Shi HB, Sugimoto H (2013) Study of crop coefficient and the ratio of soil evaporation to evapotranspiration in an irrigated maize field in an arid area of Yellow River Basin in China. Meteorol Atmos Phys 121, 207-14.

8. Tino S, Upadhyay SL, Naidu MCA, Kavani KM, Patel DR (2015) Study and analysis of various factors affecting evaporation loss of liquid nitrogen storage vessels and detailing of standard procedure for measurement of such loss rate. Indian J Cryogenics 40, $12-7$.
9. Liu CM, Zhang XY, Zhang YQ (2002) Determination of daily evaporation and evapotranspiration of winter wheat and maize by large-scale weighing lysimeter and micro-lysimeter. Agr Forest Meteorol 111, 109-20.

10. Zhang XY, Pei D, Hu CS (2003) Conserving groundwater for irrigation in the North China Plain. Irrigat Sci 21, 159-66.

11. Gao Y, Yang L, Shen X, Li X, Sun J, Duan A, Wu L (2014) Winter wheat with subsurface drip irrigation (SDI): Crop coefficients, water-use estimates, and effects of SDI on grain yield and water useefficiency. Agr Water Manag 146, 1-10.

12. Malash NM, Flowers TJ, Ragab R (2008) Effect of irrigation methods, management and salinity of irrigation water on tomato yield, soil moisture and salinity distribution. Irrigat Sci 26, 313-23.

13. Smajstrla AG, Zazueta FS (1988) Simulation of irrigation requirements of Florida agronomic crops. Soil Crop Sci Soc Fla Proc 47, 78-82.

14. Allen RG, Pereira LS, Smith M, Raes D, Wright JL (2005) FAO-56 dual crop coefficient method for estimating evaporation from soil and application extensions. J Irrigat Drain Eng 131, 2-13.

15. Bautista-Capetillo C, Zavala M, Martínez-Cob A (2013) Using thermal units for crop coefficient estimation and irrigation scheduling improves yield and water productivity of corn (Zea mays L.). J Irrigat Drain Eng 139, 214-20.

16. Marsal J, Johnson S, Casadesus J, Lopez G, Girona J, Stöckle C (2014) Fraction of canopy intercepted radiation relates differently with crop coefficient depending on the season and the fruit tree species. Agr Forest Meteorol 184, 1-11.

17. Pereira LS, Alves I (2005) Crop water requirements. In: Hillel D (ed) Encyclopedia of Soils in the Environment, Elsevier, pp 322-34.

18. Allen RG (2000) Using the FAO-56 dual crop coefficient method over an irrigated region as part of an evapotranspiration intercomparison study. $J$ Hydrol 229, 27-41.

19. Zhang BZ, Liu Y, Xu D, Zhao NN, Lei B, Rosa RD, Paredes P, Paço TA, Pereira LS (2013) The dual crop coefficient approach to estimate and partitioning evapotranspiration of the winter wheat-summer maize crop sequence in North China Plain. Irrigat Sci 31, 1303-16.

20. Xinjiang Production and Construction Group (2014) Xinjiang Production and Construction Group Yearbook, China Statistics Press, Urumqi, Xinjiang, China [in Chinese].

21. Raes D, Munoz G (2009) The ETo Calculator Reference Manual Version 3, Food and Agriculture Organization of the United Nations, Rome, Italy.

22. Jensen ME, Burman RD, Allen RG (1990) Evapotranspiration and Irrigation Water Requirements, American Society of Civil Engineers, New York. 
23. Yu LP, Huang GH, Liu HJ, Wang XP, Wang MQ (2009) Experimental investigation of soil evaporation and evapotranspiration of winter wheat under sprinkler irrigation. Agr Sci China 8, 1360-8.

24. Zhao N, Liu Y, Cai J, Rosa RD, Paredes P, Pereira LS (2013) Dual crop coefficient modelling applied to the winter wheat-summer maize crop sequence in North China Plain: basal crop coefficients and soil evaporation component. Agr Water Manag 117, 93-105.

25. Kang SZ, Zhang L, Liang YL, Hu XT, Cai HJ, Gu BJ (2002) Effects of limited irrigation on yield and water use efficiency of winter wheat in the Loess Plateau of China. Agr Water Manag 55, 203-16.

26. Wohlfahrt G, Irschick C, Thalinger B, Hörtnagl L, Obojes N, Hammerle A (2010) Insights from independent evapotranspiration estimates for closing the energy balance: a grassland case study. Vadose Zone J 9, 1025-33.

27. Lei HM, Yang DW (2010) Interannual and seasonal variability in evapotranspiration and energy partitioning over an irrigated cropland in the North China Plain. Agr Forest Meteorol 150, 581-9.

28. Wei Z, Liu Y, Xu D, Cai JB (2014) Evapotranspiration and ratio of soil evaporation to evapotranspiration of winter wheat and maize. In: Advanced Engineering Solutions, Applied Mechanics and Materials vol 539, pp 832-7.

29. Shi ZL, Jing Q, Cai J, Jiang D, Cao WX, Dai TB (2012) The fates of $15 \mathrm{~N}$ fertilizer in relation to root distributions of winter wheat under different $\mathrm{N}$ splits. Eur J Agron 40, 86-93.

30. Sun HY, Liu CM, Zhang XY, Shen YJ, Zhang YQ (2006) Effects of irrigation on water balance, yield and WUE of winter wheat in the North China Plain. Agr Water Manag 85, 211-8.

31. Sadras VO, Rodriguez D (2010) Modelling the nitrogen-driven trade-off between nitrogen utilisation efficiency and water use efficiency of wheat in eastern Australia. Field Crop Res 118, 297-305.

32. Kang S, Gu B, Du T, Zhang J (2003) Crop coefficient and ratio of transpiration to evapotranspiration of winter wheat and maize in a semi-humid region. Agr Water Manag 59, 239-54. 